\title{
Phosphorus fractions in soil after successive crops of Pinus taeda L. without fertilization
}

\author{
Luciano Colpo Gatiboni ${ }^{1 *}$ Cristiane Ottes $\operatorname{Vargas}^{1}$ Jackson Adriano Albuquerque $^{1}$ \\ Jaime Antonio Almeida ${ }^{1}$ James Stahl ${ }^{2}$ Djalma Miller Chaves ${ }^{2}$ Gustavo Brunetto $^{3}$ \\ Daniel João Dall'Orsoletta ${ }^{1}$ Luiz Paulo Rauber ${ }^{4}$
}

\author{
${ }^{1}$ Universidade do Estado de Santa Catarina (UDESC), Av. Luis de Camões 2090, 88520-000, Lages, SC, Brasil. E-mail: lgatiboni@gmail.com. \\ ${ }^{*}$ Corresponding author. \\ ${ }^{2}$ Departamento de Pesquisa e Desenvolvimento Klabin S.A. \\ ${ }^{3}$ Universidade Federal de Santa Maria (UFSM), Santa Maria, RS, Brasil. \\ ${ }^{4}$ Universidade do Oeste de Santa Catarina (UNOESC), Santa Catarina, SC, Brasil.
}

\begin{abstract}
Pinus cultivation without fertilization is a common practice in southern Brazil, which can induce a decline in the availability of phosphorus $(P)$ in the soil. The purpose of this study was to evaluate the changes in phosphorus fractions in a Humic Cambisol subjected to continuous Pinus taeda L. cultivation without fertilization. Two forest stands were evaluated, after 16 years of Pinus cultivation ( $1^{\text {st }}$ crop) and 49 years ( $3^{\text {rd }}$ crop), when soil samples were collected (layers 0-10, 10-20, 20-40, 40-60, and 60-80cm) from six trenches per forest. In soil samples, the P contained in organic (Po) and inorganic (Pi) forms was determined by sequential chemical fractionation. Labile inorganic P fractions remained unchanged after the different cultivation periods. However, the labile organic fractions declined from the first to the third cycle (from 70.6 to $39.8 \mathrm{mg} \mathrm{dm}$ in the $0-10 \mathrm{~cm}$ layer), indicating that these forms influence the buffering capacity of labile Pi. The moderately labile organic $P$ acted as a P drain, increasing its percentage of the total, from 34.7 to $56.3 \%$, from the first to the third crop. Soil cultivation for 49 years with Pinus taeda resulted in a reduction of the organic P content, indicating that for this soil use, this $P$ form should be used to diagnose $P$ availability and fertilization requirements.

Key words: forest rotations, successive crops, phosphorus fractionation, labile phosphorus.
\end{abstract}

Frações de fósforo após cultivos sucessivos de Pinus taeda L. sem fertilização

RESUMO: O cultivo de Pinus sem uso de fertilização é uma prática comum no sul do Brasil e pode levar ao declínio da disponibilidade de fósforo (P) no solo. O objetivo deste estudo foi avaliar as modificações nas frações de fósforo em Cambissolo submetido a sucessivos cultivos de Pinus taeda L. sem fertilização. Foram avaliadas duas florestas, com 16 anos de cultivo de Pinus (1ํo cultivo) e 49 anos (3ㅜ cultivo), onde amostras de solo foram coletadas nas camadas de 0-10, 10-20, 20-40, 40-60 e 60-80cm, em seis trincheiras por floresta. Nas amostras de solo foram determinados os teores de P em formas orgânicas (Po) e inorgânicas (Pi) usando esquema de fracionamento químico sequencial. As frações inorgânicas lábeis de P não sofreram alterações com os diferentes tempos de cultivo, no entanto houve declínio das frações orgânicas lábeis do primeiro para o terceiro cultivo, passando de 70,6 para 39,8mg dm $\mathrm{m}^{-3} \mathrm{na}$ camada de 0-10 cm, indicando que essas formas atuam no tamponamento do Pi lábil. O P orgânico moderadamente lábil atuou como um dreno de P, aumentando seu percentual em relação ao total, de 34,7 para 56,3\%, do primeiro para o terceiro cultivo. O cultivo do solo por 49 anos com Pinus taeda provoca a diminuição do teor de fósforo orgânico lábil, indicando que para este tipo de uso do solo essa forma de fósforo deveria ser considerada para diagnóstico da disponibilidade de fósforo e necessidade de fertilização. Palavras-chave: rotações florestais, plantios sucessivos, fracionamento de fósforo, fósforo lábil.

\section{INTRODUCTION}

Soil management in Pinus forests should focus on the improvement of soil fertility in soils with low nutrient contents, as in the highlands in the South of the state of Santa Catarina. The Pinus forests of this region are often cultivated without fertilizer application, leading to a loss in the productive potential of the forests. Studies in South America and the South of the United States showed that fertilization at planting accelerated the growth of
Pinus taeda (BEKELE et al., 2003; FAUSTINO et al., 2013; MORO et al., 2014), generating an economic return in response to this practice.

For the soil fertility diagnosis of annual crops, the available nutrient levels are measured by soil analysis, taking only the forms of easy desorption into account. In perennial and forestry crops, the diagnosis of phosphorus (P) availability is more complex, since the longer cycle, the greater is the possibility of buffering of the most labile by the less labile forms. Over the course of time, this 
increases nutrient availability in soils under Pinus stands, as emphasized by RICHTER et al. (2006); or in successive crops on unfertilized soil, as pointed out by GATIBONI et al. (2007).

In the forests, the $\mathrm{P}$ considered available by routine soil analyses (Mehlich 1 or anionexchange resin) ignores the less labile $\mathrm{P}$ forms that may become available, especially the labile organic forms (RICHTER et al., 2006). The common determination procedures do not detect the labile organic forms available to plants. Chemical fractionation of this nutrient allowed the identification from the most labile to the most recalcitrant forms. The subsequent use of chemical extractors with low to high extraction forces is the base to the technique of $\mathrm{P}$ chemical fractionation proposed by HEDLEY et al. (1982), which removed inorganic $(\mathrm{Pi})$ and organic $\mathrm{P}(\mathrm{Po})$ from the more readily available to the most stable forms (GATIBONI et al., 2007).

The tool of chemical fractionation of $\mathrm{P}$ has become fundamental to the understanding of $\mathrm{P}$ dynamics in soils under Pinus stands, by indicating which fractions are accessible to plants. Improving the knowledge of the $\mathrm{P}$ dynamics between the different portions will make the establishment of new determination methods of $\mathrm{P}$ for Pinus crops possible, enhanced the precision of the technical recommendations of $\mathrm{P}$ fertilization. Thus, our hypothesis is that in successive forest crops without fertilization there is consumption of $\mathrm{P}$ forms other than available phosphorus, e.g., of the organic forms. In this study, we evaluated changes in the phosphorus fractions of an unfertilized Cambisol under successive Pinus taeda L. crops.

\section{MATERIALS AND METHODS}

The study was carried out in Otacílio Costa, Santa Catarina (SC), in 16 and 17-year-old Pinus taeda L. forests, in the first and third crop, respectively, of which the latter reached 49 years of continuous Pinus cultivation. Two areas of the first and third crop took place, respectively, at the coordinates $27^{\circ} 30^{\prime} 03.38^{\prime \prime} \mathrm{S} / 50^{\circ} 05^{\prime} 17.78^{\prime \prime}$ $\mathrm{W}$ and $27^{\circ} 29^{\prime} 59.92^{\prime \prime} \mathrm{S} / 50^{\circ} 03^{\prime} 25.84^{\prime \prime} \mathrm{W}$, at a distance of $1400 \mathrm{~m}$ away from each other. The mean altitude of the region is $870 \mathrm{~m}$ asl, and the climate is humid mesothermic ( $\mathrm{Cfb}$ ), according to the Köppen classification, with mild summers, a mean annual temperature of $15.9^{\circ} \mathrm{C}$ and annual rainfall between 1300 and $1400 \mathrm{~mm}$. In both areas, the soil was a Humic Cambisol according to the WRB/
FAO system, derived from siltstone of the Rio do Rastro formation; kaolinite is the predominant clay mineral and iron oxides and hydroxides are present in a lower proportion.

The studied stands were treated with the commonly used management for cellulose production, with a tree spacing of $2 \times 3 \mathrm{~m}$ and total absence of fertilization. Sampling areas were selected based on previous comparative soil surveys, to ensure homogeneity regarding soil type, altitude, sun exposure, and relief. In this way, were chosen two sites representing local forests, producing the first and third successive Pinus taeda crop, respectively. Due to the absence of an area with native vegetation near the experiments, with similar characteristics to those of the stand areas, it was decided to forgo the use of a control area without cultivation, avoiding a possible bias in the interpretation of results.

The equation: $n=(t 2$. C.V. 2)/E was used to calculated the number of sample points (n) per modal unit, where t: Student statistic at a probability level of $5 \%$; CV: coefficient of variation $(\%)$ and E: sampling error (\%), according to PÉLLICO NETTO \& BRENA (1997). A sampling error of $15 \%$ was assumed, estimated based on preliminary samplings. Thus, soil samples collecting from six profiles (six sample points per modal unit of $750 \mathrm{~m}^{2}$ ) from the layers $0-10 ; 10-20,20-40,40-60$, and 60 $80 \mathrm{~cm}$. Samples were collected for chemical analyses and undisturbed samples in cylindrical rings to determine soil density. The experiment was arranged in a factorial design in strips (Factor A - cultivation period, with two levels, and Factor B - soil layers, with five levels).

The soil samples were oven-dried at $60^{\circ} \mathrm{C}$, sieved through $2 \mathrm{~mm}$ mesh, and the chemical and physical properties analyzed (Table 1), according to the methodologies described by EMBRAPA (2011), respectively. Forest litter was analyzed for carbon content (C) in samples collected in a $0.25 \mathrm{~m}^{2}$ area, with three replications. In the field of the first crop, an amount of $16.5 \mathrm{t} \mathrm{ha}^{-1}$ of litter dry weight and a C content of $428 \mathrm{~g} \mathrm{~kg}^{-1}$ were reported while in the third crop these parameters were $21.6 \mathrm{tha}^{-1}$ and $403 \mathrm{~g} \mathrm{~kg}^{-1}$, respectively.

Phosphorus was chemically fractionated according to HEDLEY et al. (1982), modified according to CONDRON et al. (1985), as follows: samples of $0.5 \mathrm{~g}$ dry soil were subjected to sequential extraction with anion-exchange resin (AER-Pi); $\mathrm{NaHCO}_{3} \quad 0.5 \mathrm{~mol} \mathrm{~L}^{-1}\left(\mathrm{NaHCO}_{3}-\mathrm{Pi}\right.$ and $\mathrm{NaHCO}_{3}-$ $\mathrm{Po}$ ); $\mathrm{HCl} 1.0 \mathrm{~mol} \mathrm{~L}^{-1}$ (HCl-Pi) and $\mathrm{NaOH} 0.5 \mathrm{~mol}$ 
Table 1 - Chemical and physical characterization of soil in six layers, under Pinus taeda cultivation, in the first and third crop.

\begin{tabular}{|c|c|c|c|c|c|c|c|c|c|c|c|c|}
\hline Layer & \multirow{2}{*}{$\mathrm{pH}_{\text {water }}$} & $\mathrm{C}$ & $\mathrm{Al}$ & $\mathrm{Ca}$ & $\mathrm{Mg}$ & $\mathrm{K}$ & $\mathrm{P}$ & Sand & Silt & Clay & $\mathrm{m}$ & $\mathrm{V}$ \\
\hline $\mathrm{cm}$ & & $\mathrm{g} \mathrm{kg}^{-1}$ & \multicolumn{3}{|c|}{$--\mathrm{cmol}_{\mathrm{c}} \mathrm{dm}^{-3} \mathrm{cmol}_{\mathrm{c}} 100 \mathrm{dm}^{-3}---$} & \multicolumn{2}{|c|}{-------mg kg-1------- } & \multicolumn{3}{|c|}{---------------g kg } & \multicolumn{2}{|c|}{----------0\%------. } \\
\hline \multicolumn{13}{|c|}{ 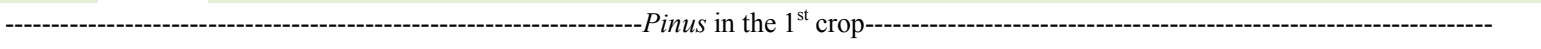 } \\
\hline $0-10$ & 4.3 & 36 & 9.6 & 7.0 & 2.5 & 65.0 & 8.2 & 182 & 336 & 482 & 49.8 & 15.1 \\
\hline $10-20$ & 4.4 & 30 & 8.2 & 8.4 & 2.5 & 67.0 & 6.0 & 147 & 415 & 438 & 42.5 & 17.0 \\
\hline $20-40$ & 4.5 & 31 & 10.4 & 7.2 & 2.1 & 61.0 & 2.2 & 120 & 278 & 602 & 52.4 & 13.7 \\
\hline $40-60$ & 4.4 & 31 & 6.1 & 4.0 & 2.0 & 55.3 & 1.2 & 120 & 278 & 602 & 49.8 & 10.6 \\
\hline $60-80$ & 4.4 & 23 & 6.6 & 3.0 & 1.5 & 59.4 & 1.8 & 145 & 259 & 596 & 58.7 & 8.1 \\
\hline \multicolumn{13}{|c|}{ 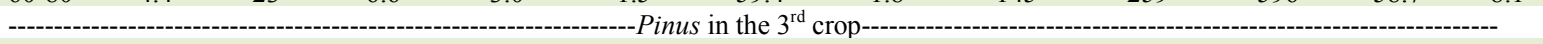 } \\
\hline $0-10$ & 4.0 & 33 & 12.3 & 0.5 & 1.2 & 36.3 & 5.7 & 178 & 358 & 464 & 87.2 & 2.9 \\
\hline $10-20$ & 4.1 & 31 & 10.3 & 0.7 & 1.1 & 25.0 & 2.5 & 228 & 359 & 413 & 84.4 & 3.0 \\
\hline $20-40$ & 4.1 & 29 & 9.7 & 0.4 & 1.4 & 28.4 & 1.1 & 236 & 255 & 509 & 83.6 & 3.0 \\
\hline $40-60$ & 4.2 & 15 & 8.7 & 0.6 & 1.0 & 31.6 & 1.8 & 197 & 354 & 449 & 83.6 & 3.2 \\
\hline $60-80$ & 4.3 & 8 & 9.1 & 0.5 & 1.0 & 32.5 & 2.6 & 180 & 264 & 556 & 85.0 & 3.0 \\
\hline
\end{tabular}

m: aluminum saturation; V: base saturation.

$\mathrm{L}^{-1}+$ ultrasound (NaOH-Pi and NaOH-Po). After the extractions, the remaining soil was oven-dried and subjected to digestion with $\mathrm{H}_{2} \mathrm{SO}_{4}+\mathrm{H}_{2} \mathrm{O}_{2}+$ $\mathrm{MgCl}_{2}$ (Residual-P). The Pi contained in the alkaline extracts $\mathrm{NaHCO}_{3}$ and $\mathrm{NaOH}$ was determined by the spectrophotometric method proposed by DICK \& TABATABAI (1977). In these alkaline extracts, total $\mathrm{P}$ was determined after digestion with ammonium persulfate + sulfuric acid in an autoclave (USEPA, 1971), and Po was computed as the difference between total $\mathrm{P}$ and $\mathrm{Pi}$. The $\mathrm{P}$ of the acid extracts was determined by the spectrophotometric method of MURPHY \& RILEY (1962).

The data were subjected to the ShapiroWilk normality test, and the non-parametric data were transformed into ranks to homogenize the variance, using the original data to interpret results. After that, the transformed data were subjected to analysis of variance. The means of data with significant effects $(\mathrm{P}<0.05)$ were compared by the paired Student's t-test $(\mathrm{P}<0.05)$ and the Scott-Knott test $(\mathrm{P}<0.05)$. For comparison of means of same layers between crops, the Student's t-test was used. The means between layers of the same crop were compared by the ScottKnott test. The linear Spearman correlation was determined between the variables $\mathrm{C}, \mathrm{NaHCO}_{3}-\mathrm{Po}$ and $\mathrm{NaOH}-\mathrm{Po}$ and software SAS (SAS, 2007) used for statistical analysis.

\section{RESULTS AND DISCUSSION}

Inorganic $\mathrm{P}$ fractions $(\mathrm{Pi})$ extracted by anion-exchange resin (AER-Pi) and sodium bicarbonate $\left(\mathrm{NaHCO}_{3}-\mathrm{Pi}\right)$ did not differ between the Pinus crop rotations in any of the studied layers (Table 2). These fractions represented the forms considered labile and have a similar buffering capacity as P absorbed by the plants (GATIBONI et al., 2007). Studying modifications in the $P$ fractions of a Cambisol, Oliveira et al. (2015) reported no differences between labile $\mathrm{P}$ fractions in a 10 -yearold Pinus taeda stand in the first crop nor native forest, indicating that; although P-deficient, these soils have a good buffering capacity of these fractions. According to the criteria of Local Soil Fertility Committee, the AER-Pi levels indicated low $(5.1-10)$ or very low P availability $(<5.0)$, regardless of the crop, confirming that the soils are P-deficient, but have a good buffering capacity of the labile fractions.

The Po fraction quantified by sodium bicarbonate $\left(\mathrm{NaHCO}_{3}-\mathrm{Po}\right)$ differed between the crops, with higher values in the first crop down to the $40-60 \mathrm{~cm}$ layer (Table 2). Values reported were approximately ten times greater than those of $\mathrm{NaHCO}_{3}-\mathrm{Pi}$, indicating that the labile $\mathrm{P}$ forms in these soils are mainly stored in organic forms. In P-deficient soils, as those studied, the organic fractions play a fundamental role in the $\mathrm{P}$ cycle and plant nutrition (SLAZAK et al., 2010). These fractions were significantly correlated with soil $\mathrm{C}$ content (R: $\left.0.73^{* *}\right)$, confirming that the presence of labile organic fractions is associated with organic matter accumulation.

The labile organic $\mathrm{P}$ forms probably buffer the inorganic forms, maintaining the labile 
Table 2 - Phosphorus contents in the different forms of Hedley fractionation and sum of the P contents extracted from the soil of Pinus taeda forests in the first and third crop.

\begin{tabular}{|c|c|c|c|c|c|c|c|c|}
\hline \multirow{2}{*}{ Layer } & AER & $\mathrm{NaHCO}_{3}$ & $\mathrm{NaHCO}_{3}$ & $\mathrm{NaOH}$ & $\mathrm{NaOH}$ & $\mathrm{HCl}$ & \multirow{2}{*}{ Residual P } & \multirow{2}{*}{$\sum$} \\
\hline & $\mathrm{Pi}$ & $\mathrm{Pi}$ & Po & $\mathrm{Pi}$ & Po & $\mathrm{Pi}$ & & \\
\hline $\mathrm{cm}$ & \multicolumn{8}{|c|}{----------------------------------------------------------------------mg dm } \\
\hline \multicolumn{9}{|c|}{ - } \\
\hline $0-10$ & $8.8 \mathrm{aA}$ & $3.4 \mathrm{aA}$ & $70.6 \mathrm{aA}$ & $19.0 \mathrm{aA}$ & $288.2 \mathrm{aB}$ & $1.1 \mathrm{bA}$ & $440.7 \mathrm{bA}$ & $830.7 \mathrm{aA}$ \\
\hline $10-20$ & $6.4 \mathrm{aA}$ & $1.9 \mathrm{bA}$ & $67.6 \mathrm{aA}$ & $16.5 \mathrm{aA}$ & $323.5 \mathrm{aA}$ & $1.1 \mathrm{bA}$ & $432.9 \mathrm{bA}$ & $849.8 \mathrm{aA}$ \\
\hline $20-40$ & $3.6 \mathrm{bA}$ & $0.9 \mathrm{bA}$ & $46.6 \mathrm{bA}$ & $13.3 \mathrm{bB}$ & $285.2 \mathrm{aA}$ & $0.7 \mathrm{cA}$ & $401.7 \mathrm{bA}$ & $752.8 \mathrm{aA}$ \\
\hline $40-60$ & $2.2 \mathrm{bA}$ & $1.5 \mathrm{bA}$ & $28.4 \mathrm{cA}$ & $14.0 \mathrm{bB}$ & $138.2 \mathrm{aA}$ & $1.3 \mathrm{bA}$ & $606.5 \mathrm{aA}$ & $791.1 \mathrm{aA}$ \\
\hline $60-80$ & $1.8 \mathrm{bA}$ & $2.7 \mathrm{aA}$ & $15.8 \mathrm{cB}$ & $9.2 \mathrm{bB}$ & $186.7 \mathrm{aA}$ & $1.8 \mathrm{aA}$ & $543.4 \mathrm{aA}$ & $759.9 \mathrm{aA}$ \\
\hline $\mathrm{CV} \%{ }^{1}$ & 43.4 & 35.2 & 40.8 & 28.6 & 57.0 & 29.7 & 32.2 & 39.8 \\
\hline \multicolumn{9}{|c|}{ - } \\
\hline $0-10$ & $5.3 \mathrm{aA}$ & $2.3 \mathrm{aA}$ & $39.8 \mathrm{aB}$ & $22.4 \mathrm{bA}$ & $404.0 \mathrm{aA}$ & $0.5 \mathrm{aA}$ & $242.6 \mathrm{bB}$ & $718.0 \mathrm{aA}$ \\
\hline $10-20$ & $2.4 \mathrm{bA}$ & $1.8 \mathrm{bA}$ & $30.4 \mathrm{aB}$ & $18.2 \mathrm{bA}$ & $322.4 \mathrm{bA}$ & $0.6 \mathrm{aA}$ & $278.7 \mathrm{bB}$ & $654.6 \mathrm{aB}$ \\
\hline $20-40$ & $1.1 \mathrm{cA}$ & $1.7 \mathrm{bA}$ & $15.9 \mathrm{bB}$ & $24.9 \mathrm{bA}$ & $281.2 \mathrm{bA}$ & $0.2 \mathrm{bA}$ & $301.2 \mathrm{bA}$ & $625.4 \mathrm{aA}$ \\
\hline $40-60$ & $1.9 \mathrm{cA}$ & $0.5 \mathrm{dA}$ & $16.2 \mathrm{bB}$ & $34.8 \mathrm{aA}$ & $215.1 \mathrm{cA}$ & $0.2 \mathrm{bA}$ & $463 \mathrm{aA}$ & $732.7 \mathrm{aA}$ \\
\hline $60-80$ & $3.0 \mathrm{bA}$ & $1.2 \mathrm{cA}$ & $26.1 \mathrm{bA}$ & $31.5 \mathrm{aA}$ & $157.5 \mathrm{cA}$ & $0.7 \mathrm{aA}$ & $493.4 \mathrm{aA}$ & $714.9 \mathrm{aA}$ \\
\hline CV\% & 30.6 & 25.2 & 37.1 & 19.9 & 28.9 & 44.6 & 21.2 & 36.1 \\
\hline
\end{tabular}

${ }^{1} \mathrm{CV} \%$ Coefficient of variation of the data; Means followed by capital letters between the crops in the same layer do not differ from each other by the $\mathrm{t}$ test $(\mathrm{P}<0.05)$; Means followed by equal lowercase letters between layers within the same crop do not differ from each other by the Scott-Knott test $(\mathrm{P}<0.05)$.

inorganic P contents unchanged, even after three Pinus crops, as also observed by SLAZAK et al. (2010). Perennial plants have more time to take up $\mathrm{P}$ during the cycle than annual crops, so that slow-release forms, such as labile Po forms, can buffer the available $\mathrm{P}$ for the forest system. Consequently, for participating in the buffering of available $\mathrm{P}$, the inorganic and organic fractions extracted from the soil by AER and $\mathrm{NaHCO}_{3}$ should be quantified together to estimate the $\mathrm{P}$ availability for perennial plants.

Apart from the buffering of plantabsorbed P, another destiny of mineralized Po may be soil resorption on the surface of iron oxides (FINK et al., 2016). In the scheme of Hedley fractionation, the inorganic $\mathrm{P}$ fractions associated with higherenergy sites, e.g., silicate clays and oxides, are supposedly extracted by $\mathrm{NaOH}$ (GATIBONI et al., 2013). The Pi contents quantified by extractor $0.5 \mathrm{~mol} \mathrm{~L}{ }^{-1} \mathrm{NaOH}+$ sonication $(\mathrm{NaOH}-\mathrm{Pi})$ showed an increase of $\mathrm{NaOH}-\mathrm{Pi}$ in the deepest soil layers under the third compared to the first Pinus crop (Table 2), indicating that this fraction acted as $\mathrm{P}$ drain. Most likely, $\mathrm{P}$ was redistributed in the profile due to the death of roots of previous crops and, in deeper layers, where there are less organic matter content and microbial activity, the soil adsorbs the mineralized phosphate.
Also, the low soil pH (Table 1) increases $\mathrm{P}$ adsorption capacity, favoring reactions with $\mathrm{Fe}$ and $\mathrm{Al}$ hydroxides, contributing to higher $\mathrm{NaOH}-\mathrm{Pi}$ and Residual-P levels in the third crop. Conversely, in the soil surface layer the presence of organic matter reduces the $\mathrm{P}$ adsorption potential of the soil, competing with phosphates for the same adsorption sites on the surface of Fe and Al oxides and hydroxides (YAN et al., 2016).

Accumulation of organic matter near the soil surface aside from competing for the same adsorption sites as mineralized $\mathrm{P}$ and reducing the content adsorbed in $\mathrm{NaOH}-\mathrm{Pi}$ increased the content of moderately labile organic $\mathrm{P}(\mathrm{NaOH}-$ Po). This fraction was higher in the soil of the third than the first crop in the $0-10 \mathrm{~cm}$ surface layer (Table 2). This increase in $\mathrm{NaOH}-\mathrm{Po}$ is expected in forest systems that promote $\mathrm{C}$ increase over time, where it comes to be a primary source in P-deficient soils (FINK et al., 2016). However, a reduction of $\mathrm{C}$ with time was observed, mainly in deeper layers, and also, the $\mathrm{NaOH}-\mathrm{Po}$ fraction was not significantly correlated with $\mathrm{C}\left(\mathrm{R}: 0.57^{\mathrm{ns}}\right)$. Despite being considered higher energy forms, in situations of $\mathrm{P}$ deficiency, the $\mathrm{P}$ fractions bound to oxides and recalcitrant organic matter can participate in the buffering of the most labile fractions. Mainly for perennial plants, due to the 
longer extraction time of these crops (GATIBONI et al., 2007; OLIVEIRA et al., 2015).

The fraction HCl-Pi estimates the calciumbound $\mathrm{P}$ forms when still in primary minerals such as apatite or in rock phosphates applied to the soil (GATIBONI et al., 2013). In the soils of this study, the values (Table 2 ) were very low $\left(<2 \mathrm{mg} \mathrm{kg}^{-1}\right)$ in all layers of both forests, confirming that the soils of the southern region of Brazil are poor in P-containing primary minerals and were not treated with any rock phosphate fertilization.

Contents of remaining $\mathrm{P}$ in the soil sample, not extracted by any of the extractors of selective fractionation (Residual-P), indicating that it is highly recalcitrant, were lower in the $0-10 \mathrm{~cm}$ and $10-20 \mathrm{~cm}$ soil layers of the third than the first crop (Table 2). This fact indicated that continuous Pinus cultivation depleted the most recalcitrant $\mathrm{P}$ forms, pointing out that they can represent a $\mathrm{P}$ source in systems with a negative nutrient balance, (GUO \& YOST 1998; GATIBONI et al., 2007).

About the relative distribution of $\mathrm{P}$ fractions in the soil, in all layers and periods of forest use, the recalcitrant (Residual-P) and moderately labile (NaOH-P) forms were the most abundant, since together they represented 87 to $97 \%$ of the total $\mathrm{P}$ extracted by fractionation (Figure 1). Nevertheless, percentages of labile P forms were small about the total $\mathrm{P}$ contents, with AER-Pi and $\mathrm{NaHCO}_{3}$-Pi together accounting for less than $1.1 \%$ in the first, and for less than $0.7 \%$ of the third forest crop. Conversely, $\mathrm{NaHCO}_{3}-\mathrm{Po}$ represented $8.5 \%$ in the first and $5.5 \%$ in the third crop, evidencing a reduction by Pinus cultivation. This fact showed that the labile P forms are mostly organic and that Pinus crops can access these fractions. However, even if these values are lower than those reported in other Pinus cultivation systems (BEKELE et al., 2003; RICHTER et al., 2006), there is no evidence of a response of Pinus to isolated $\mathrm{P}$ applications. In soils as that studied, the response to $\mathrm{P}$ applications is except just at the beginning of the stand (MORO et al., 2014).

Ratio between the labile and moderately labile inorganic forms ([AER-Pi $\left.+\mathrm{NaHCO}_{3}-\mathrm{Pi}\right]$ / $\mathrm{NaOH}-\mathrm{Pi}$ ) may indicate the balance between these $\mathrm{P}$ forms and the dynamics involving them, which theoretically are the most management-sensitive (Figure 2A). In the soil of the third crop, the proportion of labile inorganic was lower than of the moderately labile forms. Similarly, the labile organic decreased about the moderately labile forms $\left(\mathrm{NaHCO}_{3}-\mathrm{Po} / \mathrm{NaOH}-\mathrm{Pi}\right)$ from the first to the third crop, indicating an increase in less labile Po over time of forest use, or even the consumption of part of labile Po (Figure 2B). The same behavior was observed in the relationships between labile and moderately labile, organic and inorganic forms ([AER-Pi $\left.+\mathrm{NaHCO}_{3}-\mathrm{Pi}+\mathrm{NaHCO}_{3}-\mathrm{Po}\right] /$ [NaOH-Pi + NaOH-Pi]) (Figure 2C).

This reduction can be explained by the different equilibrium times of the $\mathrm{P}$ fractions, where the removal of $\mathrm{P}$ in solution by plant uptake destabilizes the balance between the fractions. This fact causes a domino effect, which, over time, causes all $\mathrm{P}$ fractions to contribute to the maintenance of the contents in solution (GUO \& YOST, 1998; GATIBONI et al., 2007). Nevertheless, it should be emphasized that while buffering by the most labile forms is fast, it is slower by the more recalcitrant forms, due to the higher binding energy of $\mathrm{P}$ to colloids. Therefore, the desorption rate of the most recalcitrant forms may fail to supply the plant demand, as pointed out by GATIBONI et al. (2007). However, the critical level of $P$ varies mostly between crops and that the relevance of the buffering of the labile by the most recalcitrant forms will therefore also be variable.

Assuming the existence of a temporal continuity in the soil between the first and third crops the $\mathrm{P}$ would be a decreasing trend in the contents of the first (more labile) fractions of the fractionation with the forest use, indicating a consumption of inorganic and organic labile forms. Concomitantly, the most recalcitrant (Residual-P) forms would decrease, since a part of the released phosphorus would be readsorbed in moderately labile Pi and Po forms ( $\mathrm{NaOH}-\mathrm{P})$. In this way, all the soil $\mathrm{P}$ forms would be in equilibrium, and the forest use would cause a slow $\mathrm{P}$ stepwise desorption effect, where the decrease in $\mathrm{P}$ availability in the most labile fractions would trigger a replenishment process, involving all forms of soil $\mathrm{P}$, including the most recalcitrant. Experiments that investigated the exhaustion of available soil P using successive crops without phosphate fertilization, such as those of GUO \& YOST (1998) and GATIBONI et al. (2007), pointed out the contribution of all soil $\mathrm{P}$ forms, including the most recalcitrant, to plant supply.

Results of this study reinforced the need for greater research efforts towards the establishment of new prediction criteria of $\mathrm{P}$ availability in perennial crops such as Pinus taeda, given the ability of these crops to exploit $\mathrm{P}$ fractions that are indefinable by 


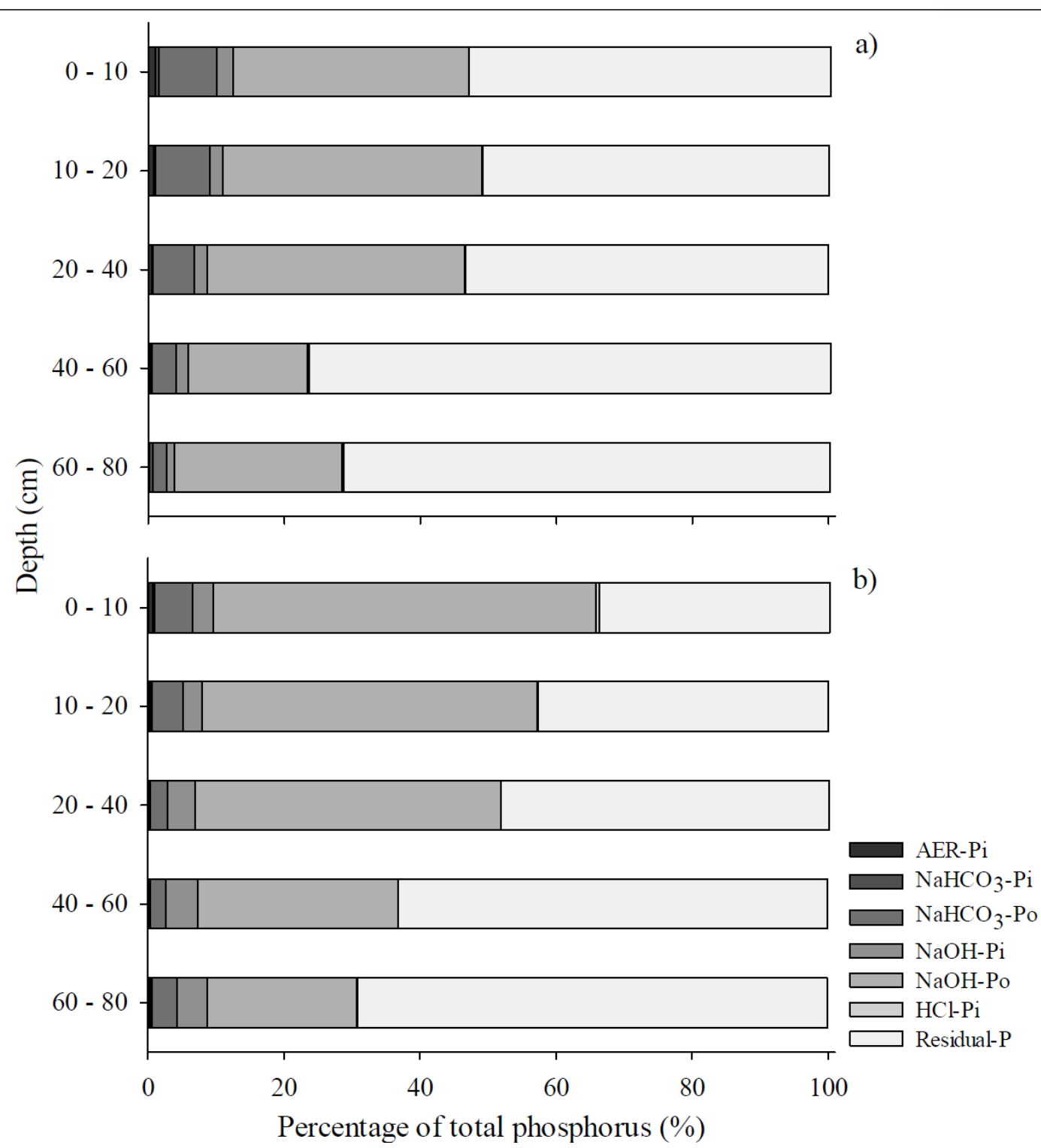

Figure 1 - Percentage distribution of the soil phosphorus fractions extracted by Hedley's chemical fractionation from a Humic Cambisolols under successive cultivation of Pinus taeda in the $1^{\text {st }}$ crop after 16 years (a) and in the $3^{\text {rd }}$ crop with 17 years (b), both without fertilizer application for 16 and 49 years, respectively.

traditional methods. Although, low P rates applied to Pinus proved promising in the soils of this region (MORO et al., 2014), the plant growth capacity in these P-poor soils in one of the areas of the world with highest Pinus productivity is surprising (CARDOSO et al., 2013). This fact reinforced the idea that the critical levels established for annual crops were not applied to perennial crops, such as Pinus taeda, and that new criteria are required, which are likely to be much lower. In this sense, in the new update of the Manual of Fertilization of
Soils of Southern Brazil, published by the Local Soil Fertility Committee (CQFS-RS/SC, 2016), different critical $\mathrm{P}$ levels are recommended. The new critical level depends on the soil type and crop requirements, and the forest species are newly classified as "low response" plants. Studies of calibration and response to phosphate fertilization of Pinus should be promoted, including analyses of the availability of $\mathrm{P}$ methods capable of quantifying the labile organic and inorganic fractions, e.g., the method based on $0.5 \mathrm{~mol} \mathrm{~L}^{-1} \mathrm{NaHCO}_{3}$. 


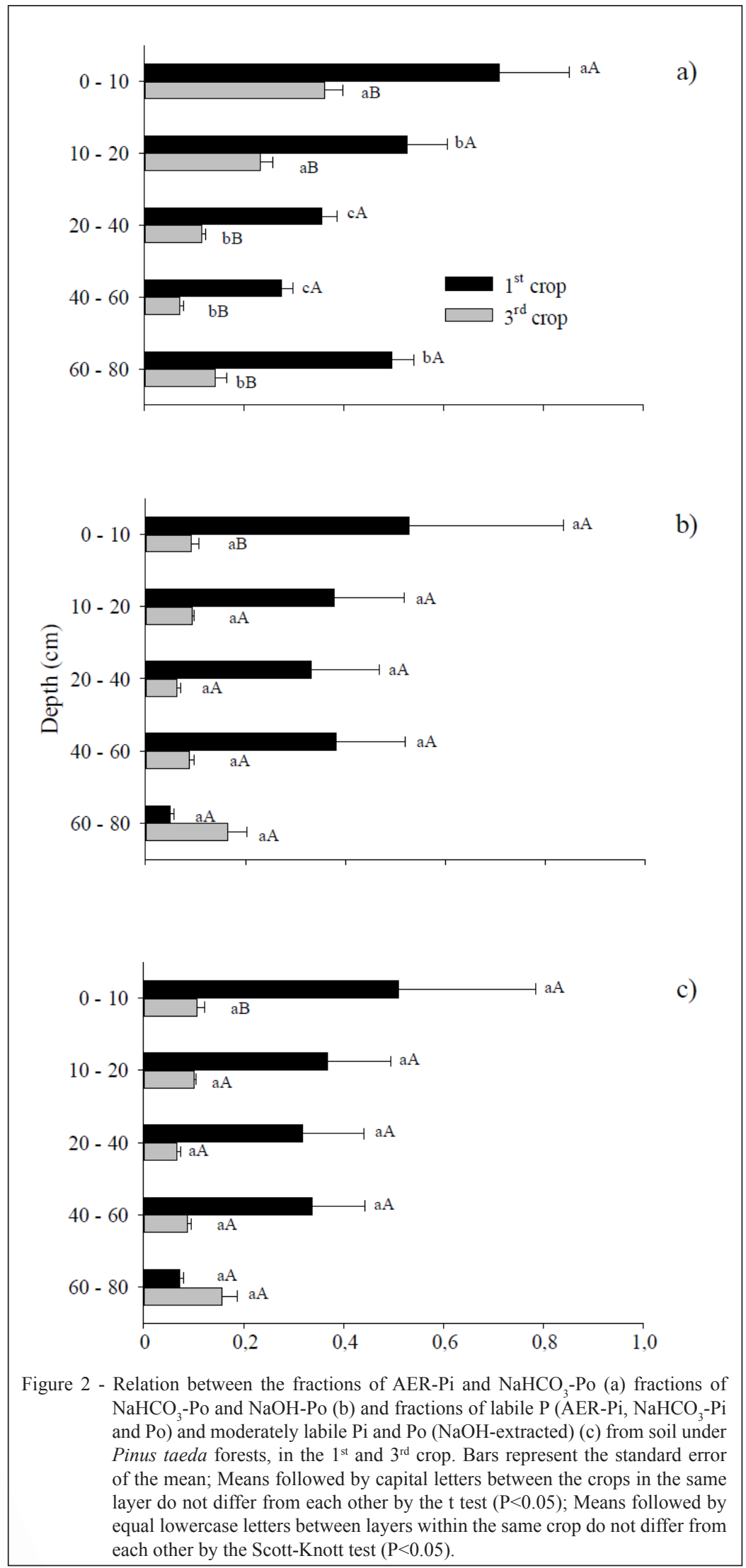

Ciência Rural, v.47, n.7, 2017. 


\section{CONCLUSION}

Successive Pinus taeda L. cultivation without soil fertilization decreases the phosphorus contents in labile inorganic and organic forms and the buffering of these by less labile forms. In soils cultivated with Pinus taeda L., labile organic $P$ should be considered an auxiliary parameter to be used together with labile inorganic $\mathrm{P}$ to diagnose the phosphorus availability and fertilization requirement.

\section{ACKNOWLEDGEMENTS}

The authors would like to thanks the Klabin Inc. for the financial support, Project FIEPE/CAV - KLABIN n ${ }^{\circ}$ 07, 29/08/2008.

\section{REFERENCES}

BEKELE, A. et al. Response of densely stocked loblolly pine (Pinus taeda L.) to applied nitrogen and phosphorus. Southern Journal of Applied Forestry, v.27,p.180-189, 2003.Available from: $<$ http://www. ingentaconnect.com/contentone/saf/sjaf/2003/00000027/00000003/ art00007>. Accessed: 18 Apr. 2017.

CARDOSO, D.J. et al. Influence of spacing regimes on the development of loblolly pine (Pinus taeda L.) in Southern Brazil. Forest Ecology and Management, v.299/310, p.761-769, 2013. Available from: <http:// www.sciencedirect.com/science/article/pii/S037811271300635X >. Accessed: 18 Apr. 2017. doi: 10.1016/j.foreco.2013.09.021.

COMISSÃO DE QUIIMICA E FERTILIDADE DO SOLO (CQFS-RS/ SC). Manual de calagem e adubação para os estados do Rio Grande do Sul e Santa Catarina. 11.ed. Frederico Westphalen: SBCS-Núcleo Regional Sul, 2016. 76p.

CONDRON, L.M. et al. Nature and distribution of soil phosphorus as revealed by a sequential extraction method followed by $31 \mathrm{P}$ nuclear magnetic resonance analysis. Journal of Soil Science, v.36, p.199-207, 1985. Available from: <http://onlinelibrary.wiley.com/ doi/10.1111/j.1365-2389.1985.tb00324.x/abstract>. Accessed: 18 Apr. 2017. doi: 10.1111/j.1365-2389.1985.tb00324.x.

DICK, W.A.;TABATABAI, M.A. Determination of orthophosphate in aqueous solutions containing labile organic and inorganic phosphorus compounds. Journal of Environmental Quality, v.6, p.82-85, 1977. Available from: <https://dl.sciencesocieties.org/publications/jeq/ abstracts/6/1/JEQ0060010082?access $=0 \&$ view $=$ pdf $>$. Accessed: 18 Apr. 2017. doi: 10.2134/jeq1977.00472425000600010018x.

EMBRAPA-Centro Nacional de Pesquisa em solos. Manual de métodos de análise de solo. 2.ed. Rio de Janeiro: Embrapa Solos, 2011. 230p.

FAUSTINO, L.I. et al. Dry weight partitioning and hydraulic traits in young Pinus taeda trees fertilized with nitrogen and phosphorus in a subtropical area. Tree Physiology, v.33, p.241-251, 2013. Available from: <http:/ treephys.oxfordjournals.org/content/early/2015/07/31/treephys.tpv068.full. pdf + html $>$. Accessed: 10 Feb. 2015. doi: 10.1093/treephys/tpv068.

FINK, J.R. et al. Adsorption and desorption of phosphorus in subtropical soils as affected by management system and mineralogy. Soil \& Tillage Research, v.155, p.62-68, 2016. Available from: $<$ http:// www.sciencedirect.com/science/article/pii/S0167198715001737>. Accessed: 18 Apr. 2017. doi: 10.1016/j.still.2015.07.017.
GATIBONI, L.C. et al. Bioavailability of soil phosphorus forms in notillage system. Revista Brasileira de Ciência do Solo, v.31, p.691-699, 2007. Available from: <http://www.scielo.br/pdf/rbcs/v31n4/a10v31n4. pdf $>$. Accessed: 10 Feb. 2014. doi: 10.1590/S0100-06832007000400010.

GATIBONI, L.C. et al. Fracionamento químico das formas de fósforo do solo: uso e limitações. In: ARAÚJO, A.P.; ALVES, B.J.R. (Org.). Tópicos em ciência do solo. Viçosa: SBCS, 2013. V.8, p.141-187.

GUO, F.; YOST, R.S. Partitioning soil phosphorus into three discrete pools of differing availability. Soil Science, v.163, n.10, p.822-833, 1998. Available from: <http://journals.lww.com/soilsci/Abstract/1998/10000/Partitioning Soil_Phosphorus_Into_Three_Discrete.6.aspx>.Accessed: 18 Apr. 2017.

HEDLEY, M.J. et al. Changes in inorganic and organic soil phosphorus fractions induced by cultivation practices and by laboratory incubations. Soil Science Society of America Journal, v.46, p.970-976, 1982. Available from: <https://dl.sciencesocieties.org/publications/sssaj/ abstracts/46/5/SS0460050970?access $=0 \& v i e w=p d f>$. Accessed: 18 Apr. 2017. doi: 10.2136/sssaj1982.03615995004600050017x.

MORO, L. et al. Response of one-, five-, and nine-year-old pinus taeda to NPK fertilization in southern Brazil. Revista Brasileira de Ciência do Solo, v.38, p.1181-1189, 2014. Available from: <http://www.scielo. br/pdf/rbcs/v38n4/14.pdf $>$. Accessed: 18 Apr. 2015. doi: 10.1590/ S0100-06832014000400014.

MURPHY, J.; RILEY, J.P. A modified single solution method for the determination of phosphate in natural waters. Analytica Chimica Acta, v.27, p.31-36, 1962. Available from: <http://www.sciencedirect.com/ science/article/pii/S0003267000884445>. Accessed: 18 Apr. 2015. doi: $10.1016 / \mathrm{S} 0003-2670(00) 88444-5$.

OLIVEIRA, C.M.B. et al. Phosphorus fractions and organic matter chemistry under different land use on Humic Cambisols in Southern Brazil. Geoderma Regional, v.5, p.140-149, 2015. Available from: $<$ http://www. sciencedirect.com/science/article/pii/S2352009415000243>. Accessed: 18 Apr. 2017. doi: 10.1016/j.geodrs.2015.06.001.

PÉLLICO NETTO, S.; BRENDA, D.A. Inventário florestal. Curitiba: UFPR, 1997. 316p.

RICHTER, D.D. et al. Bioavailability of slowly cycling soil phosphorus : major restructuring of soil $\mathrm{P}$ fractions over four decades in an aggrading forest. Oecologia, v.150, p.259-271, 2006. Available from: <https://link.springer.com/article/10.1007/s00442-006-05104>. Accessed: 18 Apr. 2017. doi: 10.1007/s00442-006-0510-4.

SAS INSTITUTE INC. SAS 9.1.3 for Windows Microsoft. Cary, 2007. (TS1M3).

SLAZAK, A. et al. Soil organic phosphorus fraction in pine - oak forest stands in Northeastern Germany. Geoderma, v.158, p.156-162, 2010. Available from: <http://doi.org/10.1016/j.geoderma.2010.04.023>. Accessed: 21 Apr. 2016. doi: 10.1016/j.geoderma.2010.04.023.

USEPA (UNITED STATES ENVIRONMENTAL PROTECTION AGENCY). Methods of chemical analysis for water and wastes. Cincinnati, 1971. Available from: <http://www.epa.gov/SW-846/ pdfs/3050b.pdf >. Accessed: 20 Jan. 2015.

YAN, J. et al. Preliminary investigation of phosphorus adsorption onto two types of iron oxide-organic matter complexes. Journal of EnvironmentalSciences, v.42,p.152-162,2016. Available from: $<\mathrm{http} / /$ www.sciencedirect.com/science/article/pii/S1001074215003824>. Accessed: 18 Apr. 2017. doi: 10.1016/j.jes.2015.08.008. 